\title{
Effects of intrauterine infusion of Escherichia coli lipopolysaccharide on uterine mRNA gene expression and peripheral polymorphonuclear leukocytes in Jersey cows diagnosed with purulent vaginal discharge
}

\author{
João G. N. Moraes, ${ }^{\star 1}$ Luís G. D. Mendonça, ${ }^{*}$ Paula R. B. Silva, ${ }^{*}$ Alexandre A. Scanavez, ${ }^{*}$ Klibs N. Galvão,† \\ Michael A. Ballou, $\ddagger$ Milli Worku, $\S$ and Ricardo C. Chebel ${ }^{*} \#^{2}$ \\ *Department of Animal Science, University of Minnesota, St. Paul 55108 \\ †Department of Large Animal Clinical Sciences, University of Florida, Gainesville 32608 \\ †Department of Animal and Food Sciences, Texas Tech University, Lubbock 79409 \\ §Department of Animal Sciences, North Carolina Agricultural and Technical State University, Greensboro 27411 \\ \#Department of Animal Sciences, University of Florida, Gainesville 32608
}

\begin{abstract}
The objectives of the current experiment were to investigate the effects of intrauterine treatment of cows with purulent vaginal discharge (PVD) using lipopolysaccharide (LPS) from Escherichia coli on uterine mRNA expression of genes related to inflammatory responses, peripheral polymorphonuclear leukocyte (PMN) function, hematological parameters, and blood concentrations of cortisol, haptoglobin, and progesterone (P4). Jersey cows $(\mathrm{n}=3,084)$ were examined for PVD at 35 $\pm 6 \mathrm{~d}$ postpartum using the Metricheck device (Simcro, Hamilton, New Zealand). At examination, 310 cows had PVD (10.1\%), but to ensure proper collection and processing of samples, 267 cows were used in this experiment. Cows were balanced for lactation number, body condition score, and milk yield, and randomly assigned to the control treatment [intrauterine infusion of $20 \mathrm{~mL}$ of phosphate-buffered saline (PBS); $\mathrm{n}=87$ ] or to receive intrauterine infusion of $20 \mathrm{~mL}$ of PBS containing $150 \mu \mathrm{g}$ (LPS150; $\mathrm{n}=91$ ) or $300 \mu \mathrm{g}$ (LPS300; $\mathrm{n}$ $=89)$ of $E$. coli LPS. Uteri were biopsied in a subgroup of cows at $6 \mathrm{~h}$ after infusion and in another subgroup of cows at $24 \mathrm{~h}$ after infusion. Peripheral PMN expression of adhesion molecules (L-selectin and MAC-1) and phagocytosis and oxidative burst were evaluated at 0,2 , and $6 \mathrm{~h}$ after infusion. Blood sampled $0,2,6$, 24,48 , and $168 \mathrm{~h}$ after infusion was used for complete hemogram and to determine concentrations of cortisol, haptoglobin, and P4. Treatment did not affect uterine mRNA expression of adhesion molecules [endothelial leukocyte adhesion molecule (E-selectin), intracellular
\end{abstract}

\footnotetext{
Received June 20, 2016.

Accepted February 2, 2017.

${ }^{1}$ Current address: Division of Animal Sciences, University of Missouri, Columbia, MO.

${ }^{2}$ Corresponding author: rcchebel@ufl.edu
}

adhesion molecule-1 (ICAM-1), and vascular cell adhesion molecule-1 (VCAM-1)], cytokines (tumor necrosis factor- $\alpha$, IL-1 $\beta$, IL-6, IL-8, and IL-10), and toll-like receptor-4. Treatment did not affect PMN expression of L-selectin, but intensity of expression of MAC-1 was higher for LPS150 cows than PBS cows, and tended to be higher in LPS150 than LPS300 cows. Furthermore, a greater percentage of PMN from LPS300 cows were positive for phagocytosis and oxidative burst compared with PBS and LPS150 cows. No effects were observed of treatment on hematological parameters and concentrations of cortisol, haptoglobin, and $\mathrm{P} 4$. These observations suggest that intrauterine infusion of $E$. coli LPS moderately stimulates peripheral PMN function, but further research is needed to better understand the immunomodulatory effects of LPS in the uterus of cows with PVD.

Key words: lactating dairy cow, purulent vaginal discharge, lipopolysaccharide

\section{INTRODUCTION}

Reproductive failure, the most important reason for involuntary culling of dairy cows (NAHMS, 2007), greatly affects profitability of the cattle industry. $\mathrm{Pu}-$ rulent vaginal discharge (PVD), formerly described as clinical endometritis (Dubuc et al., 2010), is usually associated with bacterial infection, affects approximately $20 \%$ of postpartum dairy cows (Dubuc et al., 2010; Galvão, 2012), and is associated with reproductive failure, reduced milk production, and increased culling (Gilbert et al., 2005; Sheldon et al., 2009). The term PVD has been proposed to be used instead of clinical endometritis because endometrial inflammation is not always present in cows with PVD (Dubuc et al., 2010). Commonly reported bacteria from the uterus of cows with PVD were identified using culture-dependent methods and include Arcanobacterium pyogenes, Esch- 
erichia coli, Prevotella melaninogenicus, Fusobacterium spp., Streptococcus spp., Staphylococcus spp., Pasteurella multocida, Clostridium spp., and Bacillus licheniformis (Williams et al., 2005).

Immune deficiency during the prepartum period is one of the most important factors predisposing periparturient dairy cows to uterine diseases (LeBlanc, 2008). In cows diagnosed with metritis and endometritis, phagocytic capacity of neutrophils isolated from peripheral blood increases from parturition to the third week postpartum, but the number and phagocytic capacity of neutrophils recovered from the uterus declines from the first to the third week postpartum (Mateus et al., 2002; Hammon et al., 2006). The cause of such asynchrony between peripheral blood and uterine neutrophil activity has not been determined, but it is possible that the reduced counts of bacteria in the uterus and increased concentrations of progesterone (P4) may reduce the chemotactic stimulus to the uterus (Mateus et al., 2002).

Intrauterine treatment of cows with PVD using cephapirin benzathine is approved in Canada, Europe, and New Zealand (Galvão, 2012), but no products are currently approved in the United States for treatment of PVD. Although intrauterine treatment of cows with PVD and with subclinical endometritis using cephapirin benzathine improved reproductive performance (LeBlanc et al., 2002; Kasimanickam et al., 2005), intrauterine infusion with other antimicrobials may inhibit phagocytic activity of neutrophils in the uterus (Masera et al., 1980; Oxender and Seguin, 1976), which may compromise resolution of uterine infections. Furthermore, the increased concern regarding the use of antimicrobials in food-producing animals and possible antibiotic resistance stimulates the search for nonantimicrobial therapies for treatment of PVD. Lipopolysaccharide present in the outer membrane of gram-negative bacteria cell wall plays an important role in pathogen recognition and triggering the subsequent inflammatory response (Mogensen, 2009) and has been used as an immunomodulator. Vaccination of cows with the rough mutant $E$. coli O111:B14, commonly known as J5, elicits a strong immune response and protection against coliform mastitis and clinical signs associated with endotoxemia (González et al., 1989). Furthermore, intrauterine infusion of repeat breeder cows diagnosed with endometritis with $100 \mu \mathrm{g}$ of $E$. coli LPS resulted in elimination of uterine bacterial infection in $75 \%$ of treated cows and increased intrauterine total leukocyte count, proportion of PMN in uterine cytology, and proportion of live PMN in the uterus (Singh et al., 2000).

In mammals, the recognition of bacterial LPS occurs through the toll-like receptor-4 (TLR-4) and myeloid differentiation factor 2 complex (Park et al., 2009). Upon binding of LPS to the TLR4 and myeloid differentiation factor 2 complex, transcription factors such as nuclear factor- $\kappa \mathrm{B}$, and members of the interferon-regulatory factor family are activated (O'Neill and Bowie, 2007; Lu et al., 2008), stimulating the production of cytokines (Wright, 1999) that stimulate both innate and adaptive immunity (Li and Verma, 2002; Schroder et al., 2004). The increased secretion of cytokines and chemokines in response to LPS stimulate the expression of integrin adhesion molecules LFA-1 (CD11aCD18) and MAC-1 (CD11bCD18) by neutrophils and stimulates the migration of leukocytes to sites of inflammation (Harada et al., 1994). Furthermore, LPS activation of nuclear-factor $\kappa \mathrm{B}$ stimulates cyclooxygenase-2 (MacKenzie et al., 2013), resulting in increased secretion of prostaglandins, which may interfere with function of corpora lutea (CL) and cause a decrease in P4 concentrations (Herath et al., 2006).

The hypothesis of the current experiment was that intrauterine treatment of cows with PVD with $E$. coli LPS would modulate uterine mRNA expression of genes related to the inflammatory response, increase peripheral PMN expression of adhesion molecules and activity (phagocytosis and oxidative burst), increase blood cortisol and haptoglobin concentrations, and stimulate luteolysis in cows with a functional CL. Our objectives were to investigate the effects of intrauterine treatment of cows with PVD with LPS from E. coli on uterine mRNA expression of genes related to the inflammatory response, peripheral PMN function, hematological parameters, and circulating concentrations of cortisol, haptoglobin, and P4.

\section{MATERIALS AND METHODS}

\section{Cows and Treatments}

The experiment was conducted from December 2010 to May 2012 in a commercial free-stall dairy located in Nicollet, Minnesota. Cows were milked thrice daily and were fed a TMR twice daily. Cows were examined in the morning upon return from the milking parlor while they were restrained in self-locking head stanchions. Lactating Jersey cows $(\mathrm{n}=3,084)$ were examined for PVD at $35 \pm 6$ DIM postpartum using the Metricheck device (Simcro, Hamilton, New Zealand; McDougall et al., 2007). Cows with $\geq 50 \%$ of pus in the exudate retrieved from the vagina were considered positive for PVD (Sheldon et al., 2006). Despite the fact that it is not possible to affirm that PVD was a consequence of uterine infection, $69 \%$ of the cows with PVD in the present experiment had $\geq 6 \%$ of PMN in a uterine cy- 
tology sample collected immediately before LPS treatment (Moraes et al., 2017). Furthermore, occurrence of retained placenta and metritis increased the odds for PVD 4 to 10 times (Moraes et al., 2017). A total of 2,664 cows had $<50 \%$ of pus in the retrieved exudate, and 420 cows $(13.6 \%)$ had $\geq 50 \%$ of pus in the retrieved exudate. Cows with $\geq 50 \%$ of pus in the vaginal exudate were examined by palpation per rectum of the uterine contents by a single veterinarian, and cows that had palpable fluid in the uterus were removed from the experiment $(\mathrm{n}=110)$ because they were believed to have pyometra, which would require systemic treatment with $\mathrm{PGF}_{2 \alpha}$. Of the 310 remaining cows positive for PVD, 267 cows were used in the experiment because a maximum of 9 cows could be treated per day to ensure proper collection and timely processing of samples. Scores for PVD were given based on visual observation of retrieved exudate, which was placed on a black plastic plate to improve visualization. Purulent vaginal discharge was scored as follows: mild, 50 to $60 \%$ of the retrieved vaginal exudate was pus; moderate, 60 to $90 \%$ of the retrieved vaginal exudate was pus; and severe, $>90 \%$ of the retrieved vaginal exudate was pus. The percentages of cows with mild, moderate, and severe PVD diagnosed with $\geq 10 \%$ PMN in uterine cytology before intrauterine infusion were $36.7,51.9$, and $94.1 \%$, respectively.

Within enrollment day, cows with PVD were balanced for lactation number, BCS (1 to 5, 0.25 unit increments; Ferguson et al., 1994), PVD score (mild, moderate, severe), and weekly average milk yield, and were randomly assigned to 1 of 3 treatments. Cows enrolled in the control treatment received an intrauterine infusion of $20 \mathrm{~mL}$ of PBS $(\mathrm{n}=87)$, cows enrolled in the LPS150 treatment received an intrauterine infusion of $20 \mathrm{~mL}$ of PBS containing $150 \mu \mathrm{g}$ of E. coli LPS $(\mathrm{n}=91)$, and cows enrolled in the LPS300 treatment received an intrauterine infusion of $20 \mathrm{~mL}$ of PBS containing $300 \mu \mathrm{g}$ of $E$. coli LPS $(\mathrm{n}=89)$. The doses used in the current experiment are based on the experiment by Singh et al. (2000) who used $100 \mu \mathrm{g}$ of LPS in cows producing $\leq 10 \mathrm{~kg}$ of milk per day. Lyophilized LPS from E. coli serotype O26:B6 containing 10,000 endotoxin units per mg of LPS (catalog no. L8274, SigmaAldrich, St. Louis, MO) was reconstituted by adding sterile PBS (pH 7.4, $137 \mathrm{mM}$ sodium chloride, $2.7 \mathrm{mM}$ potassium chloride, $12 \mathrm{~m} M$ phosphate buffer; catalog no. E504, Amresco LLC, Solon, OH), and solutions at $1 \mathrm{mg} / \mathrm{mL}$ were stored in silanized containers (catalog no. $27225-\mathrm{U}$, Sigma-Aldrich) at $-80^{\circ} \mathrm{C}$. The solution of LPS used for the intrauterine treatments (150 and 300 $\mu \mathrm{g}$ of LPS) were prepared at each morning before infusions, using glassware that had been previously treated with Sigmacote (catalog no. SL2, Sigma-Aldrich) to inhibit LPS from binding to the glassware. The LPS solutions were transported from the farm's laboratory to the pens inside a cooler without icepacks, and solutions were at room temperature when infused in the uterus. For the intrauterine infusions, an infusion pipette (Infuse-Eze Pipette, Jorgenson Labs, Loveland, $\mathrm{CO})$ was directed to the base of the larger uterine horn (when the distinction was possible) and solutions were infused. Cows were treated $24 \mathrm{~h}$ after diagnosis of PVD and enrollment in the experiment.

\section{Uterine Biopsies}

A subgroup of cows was selected randomly to have an uterine sample collected $6 \mathrm{~h}$ after the intrauterine infusion $(\mathrm{PBS}=18, \mathrm{LPS} 150=18, \mathrm{LPS} 300=17)$, and another subgroup of cows was selected randomly to have an uterine sample collected at $24 \mathrm{~h}$ after intrauterine infusions $(\mathrm{PBS}=18, \mathrm{LPS} 150=19, \mathrm{LPS} 300=18)$. The collection of uterine biopsy samples was not possible in 5 cows $(6 \mathrm{~h}: \mathrm{PBS}=2$ and LPS150 = 1; $24 \mathrm{~h}: \mathrm{LPS} 150=$ 1 and LPS300 = 1) because the veterinarian could not pass the biopsy instrument through the cervix.

Uterine biopsies were collected as described previously (Galvão et al., 2011). Briefly, cows were given epidural anesthesia $(4 \mathrm{~mL}$ of $2 \%$ lidocaine, Lidocaine Injectable, Aspen Veterinary Resources Ltd., Liberty, MO), and samples were collected using a Hauptner biopsy instrument that was protected with a sanitary chemise (IMV Technologies, L'Aigle, France), which was broken immediately before the biopsy tool was passed through the cervical os. Biopsies (weighed between 100 and $200 \mathrm{mg}$ ) were collected from the base of the larger horn and placed in 2-mL microcentrifuge tubes containing $1 \mathrm{~mL}$ of a commercial sample buffer (RNAlater, Ambion-Applied Biosystems, Life Technologies Corporation, Carlsbad, CA) and frozen at $-80^{\circ} \mathrm{C}$ until RNA isolation.

\section{RNA Isolation and Purification}

Isolation and purification of total RNA was performed as previously described (Cerri et al., 2012). Briefly, uterine samples were removed from the $-80^{\circ} \mathrm{C}$ freezer and kept on shaved ice until extraction. Total RNA was extracted using TRIzol reagent (Invitrogen Corp., Carlsbad, CA) and purified using a PureLink RNA Mini Kit (Invitrogen Corp.) according to the manufacturer's protocol. The RNA concentration and purity were determined using the Agilent 2100 Bioanalyzer Nano Drop 2000 Spectrophotometer (Thermo Scien- 
tific, Wilmington, DE). Samples were aliquoted and stored at $-80^{\circ} \mathrm{C}$ until amplification.

\section{Quantitative, Real-Time, Reverse-Transcription PCR}

Quantitative RT-PCR was performed using Applied Biosystems 7500 Real-Time PCR system (Applied Biosystems, Life Technologies Corporation) as described previously (Ozawa et al., 2013). Briefly, RNA samples (50 ng/reaction) were incubated with RNase-free DNase I (New England BioLabs, Ipswich, MA) for 15 min at $37^{\circ} \mathrm{C}$, heat denatured $\left(75^{\circ} \mathrm{C}\right.$ for $\left.10 \mathrm{~min}\right)$, and then reverse transcribed using a High Capacity cDNA Reverse Transcription Kit and random hexamers (Applied Biosystems) and amplified with SYBR Green PCR Master Mix reagent (Applied Biosystems) under PCR normal conditions (40-50 cycles of $95^{\circ} \mathrm{C}$ for 15 $\mathrm{s}$ and $60^{\circ} \mathrm{C}$ for $1 \mathrm{~min}$ ). Primers used in the current experiment were designed using Primer Express v2.0 (Applied Biosystems) and are shown in Table 1. Mitochondrial ribosomal protein S15 (MRPS15) was used as housekeeping gene as this has been shown to be the most stable normalizer gene in uterine samples from postpartum cows (Chapwanya et al., 2009). A standard curve was built for each gene of interest by doing four 1:5 dilutions starting with $100 \mathrm{ng} / \mu \mathrm{L}$ of cDNA solution. The efficiency of the amplification was calculated and only primer sets with efficiency $>90 \%$ were used. Specificity of amplification of each primer set was examined by dissociation curve analysis and only sets with one single peak were used. All reactions were done in triplicate and triplicate samples with cycle threshold (Ct) coefficient of variation $>1 \%$ were repeated. A no template control was run for each primer used on every 96-well plate. Fold change (n-fold) in gene expression was calculated using the relative quantitation method $\left(2^{-\mathrm{ddCt}}\right)$. The average of the delta $\mathrm{Ct}$ (calculated using the MSPR15 as reference gene) in the control samples (PBS) was used to calculate the delta delta Ct (ddCt) and then the fold change.

\section{Peripheral PMN Activity}

Ex vivo PMN expression of adhesion molecules and activity (phagocytosis and oxidative burst) were evaluated from a subgroup of 25 cows per treatment at 0,2 , and $6 \mathrm{~h}$ relative to treatment as previously described (Hulbert et al., 2011). Blood samples were collected into heparinized evacuated tubes (Becton Dickinson Vacutainer Systems, Franklin Lakes, NJ). Expression of leukocyte adhesion molecule-1 (L-selectin) and MAC-1 by PMN was determined by indirect immunofluorescence staining. The assay consisted of incubating 200 $\mu \mathrm{L}$ of whole blood at $4^{\circ} \mathrm{C}$ for 30 min with $5 \mu \mathrm{g} / \mathrm{mL}$ of anti-bovine CD62L (DU1-29, VMRD Inc., Pullman, WA) monoclonal antibody produced in mouse or 2.5 $\mu \mathrm{g} / \mathrm{mL}$ of anti-bovine MAC-1 (BAQ30A, VMRD Inc.) monoclonal antibody produced in mouse. Prior to the incubation of cells with an anti-mouse IgG-FITC secondary polyclonal antibody (AbD Serotec, Raleigh, NC) diluted 1:400 in PBS solution (Sigma-Aldrich), erythrocytes were lysed with hyper-concentrated PBS solution. After washing the cells with PBS solution, samples were analyzed by flow cytometry. Blood from nondiseased cows were used as positive and negative controls in all assays. Negative controls consisted of incubating $200 \mu \mathrm{L}$ of PBS solution instead of the monoclonal antibody. Phagocytic and oxidative burst

Table 1. Primers used for quantitative reverse-transcription PCR

\begin{tabular}{llll}
\hline Gene $^{1}$ & GenBank ID & Primer & Sequence $\left(5^{\prime}\right.$ to $\left.3^{\prime}\right)$ \\
\hline MRPS15 & NM_001192201.1 & Forward & AGATGACCCGCCCCCTTCCA \\
& & Reverse & GGGAGCTGGTGTCCTTCGGG \\
E-selectin & NM_174181.2 & Forward & AGGCCACTCGGTGCATGTC \\
ICAM-1 & NM_174348.2 & Reverse & FAACCTGGGTTGGCCCCTGC \\
& & Reverse & GGGCCTGCCGTGCTCCTTAC \\
$V C A M-1$ & NM_174484.1 & Forward & AGGGCTCAGTTAGAGGATGCGGG \\
& & Reverse & CAAGGAAGCCTGAACCCCAGT \\
TNF- $\alpha$ & NM_173966.2 & Forward & ACACACCCCCGAGAGACAGCC \\
& & Reverse & TGGGGGCCGATTACCCCGAA \\
$I L-1 \beta$ & NM_174093.1 & Forward & GCTTCAGGCAGGTGGTGTCGG \\
& & Reverse & GCACGGGTGCGTCACACAGA \\
$I L-6$ & NM_173923.2 & Forward & ATTCGCTGTCTCCCTGGGGCT \\
& & Reverse & AGTCTGCCTGGGGTGGTGTCAT \\
$I L-8$ & NM_173925.2 & Forward & TGGCTGTTGCTCTCTTGGCAGC \\
& & Reverse & CCTGCACAACCTTCTGCACCCA \\
$I L-10$ & NM_174088.1 & Forward & GAGAGTCTTCAGTGAGCTCCAAGAG \\
& & Reverse & GCATCTTCGTTGTCATGTAGGTTT \\
\hline
\end{tabular}

${ }^{1}$ MRPS15 = mitochondrial ribosomal protein S15; TNF- $\alpha=$ tumor necrosis factor- $\alpha$. 
activity of peripheral PMN was determined upon challenge with enteropathogenic bacteria (E. coli O118:H8) as previously described (Hulbert et al., 2011). Briefly, the assay to determine phagocytosis and oxidative burst consisted of incubating $200 \mu \mathrm{L}$ of whole blood with $100 \mu M$ dihydrorhodamine 123 (Molecular Probes, Invitrogen Corp.), an oxidative-sensitive indicator, and $40 \mu \mathrm{L}$ of fluorescently labeled bacteria $\left(10^{9} \mathrm{cfu} / \mathrm{mL}\right)$ at $38.5^{\circ} \mathrm{C}$ for $15 \mathrm{~min}$, with surface bacteria fluorescence removed using the Trypan Blue Solution (0.4\%; SigmaAldrich). After washing with milliQ water to remove excess dye, erythrocytes were lysed by the addition of hyper-concentrated PBS solution (Sigma-Aldrich). Lastly, the cells were resuspended in PBS solution for immediate flow cytometry analysis. Blood from nondiseased cows were used as positive and negative controls. Unlabeled bacteria were used as negative controls for the phagocytosis assay and samples that received no dihydrorhodamine 123 served as negative controls for the oxidative burst assay. All flow cytometry data were collected on a BD FACSCanto II (BD Biosciences, Franklin Lakes, NJ) and analyzed using FlowJo 7.6.4 software (Tree Star Inc., San Carlos, CA). The PMN population was identified on basis of forward- and sidescattered properties. After strictly gating the PMN population, data from 3 parameters were collected for analysis: forward scatter, side scatter, and log fluorescence. Intensity of phagocytosis, oxidative burst, and expression of MAC-1 and L-selectin molecules by PMN was expressed in geometric mean fluorescence intensity. Intensity of phagocytosis and expression of adhesion molecules were an indirect indication of the number of phagocytized bacteria and antibodies against CD62L or MAC-1 adhering to PMN, respectively. Oxidative burst intensity was an indirect indication of the amount of reactive oxygen species produced via oxidation of dihydrorhodamine 123. Furthermore, percentages of PMN positive for phagocytosis and oxidative burst and for expression of MAC-1 and L-selectin molecules were calculated.

\section{Hemogram}

Blood samples collected from the median coccygeal vein or artery into evacuated tubes containing K3 EDTA (Becton Dickinson Vacutainer Systems) from a subgroup of cows (PBS, $\mathrm{n}=38$; LPS150, $\mathrm{n}=40$; LPS300, $\mathrm{n}=41$ ) at $0,2,6,24$, and $48 \mathrm{~h}$ after treatment were used for hemogram. Samples were analyzed using a Vet Scan HM2 (Abaxis, Union City, CA) machine. Complete blood count was performed but only data referent to counts of leukocytes, lymphocytes, monocytes and granulocytes are reported.

\section{Haptoglobin, Progesterone, and Cortisol Assays}

Blood samples $(7 \mathrm{~mL})$ were collected from the median coccygeal vein or artery using evacuated tubes. Samples were immediately placed in ice and transported to the laboratory within $5 \mathrm{~h}$ of collection. Blood tubes were centrifuged at $2,000 \times g$ for $15 \mathrm{~min}$ at $4^{\circ} \mathrm{C}$ for serum or plasma separation. Serum and plasma samples from individual cows were frozen at $-25^{\circ} \mathrm{C}$ until analyzed.

Blood samples were collected from all cows at 0,1 , 2 , and $7 \mathrm{~d}$ relative to intrauterine infusions. Samples collected into evacuated tubes without anti-coagulant (Becton Dickinson Vacutainer Systems) were used to determine haptoglobin concentration by a colorimetric procedure using a plate reader (Spectramax 340; Molecular Devices, Sunnyvale, CA) to measure absorbance (Hulbert et al., 2011). The intra- and interassay coefficients of variation were 4.64 and $3.55 \%$, respectively. Samples collected into evacuated tubes containing $\mathrm{K}_{2}$ EDTA (Becton Dickinson Vacutainer Systems) were used to determine P4 concentration by RIA (Coata-Count Progesterone, Siemens Medical Solutions Diagnostics, Los Angeles, CA). The intraassay and interassay CV were 7.28 and $6.46 \%$, respectively. Cows with $\mathrm{P} 4$ concentration $\geq 1 \mathrm{ng} / \mathrm{mL}$ in the sample collected immediately before intrauterine infusion (d 0) were classified as having a functional CL. Cows with P4 concentration $\geq 1 \mathrm{ng} / \mathrm{mL}$ on $\mathrm{d} 0$ that had $\mathrm{P} 4$ concentration $<1 \mathrm{ng} / \mathrm{mL}$ on $\mathrm{d} 1,2$, or 7 were considered to have had luteolysis.

Blood samples collected from a subgroup of cows (PBS, $n=43$; LPS150, $n=45$; LPS300, $n=42$ ) using evacuated tubes without anticoagulant (Becton Dickinson Vacutainer Systems) at 0, 2, 4, 6, and $24 \mathrm{~h}$ after intrauterine infusion were used to determine cortisol concentration. Serum was analyzed using a solid-phase radioimmunoassay kit (Coat-a-Count, Siemens Medical Solutions Diagnostics). The intra- and interassay coefficients of variation were 9.32 and $3.59 \%$, respectively.

\section{Statistical Analysis}

Enrolled cows were balanced for lactation number, body condition score, PVD score, and weekly average milk yield. Treatments were randomly assigned to the cows using a sealed envelope. All statistical analyses were conducted using SAS (SAS version 9.4 for Windows, SAS Institute Inc., Cary, NC).

Continuous data were assessed for normality using the UNIVARIATE procedure. Continuous data that were not normally distributed were log-transformed. Continuous data without repeated measurements (mRNA expression ddCt) were analyzed by ANOVA 
using the GLM procedures of SAS. The models included the effect of treatment. Furthermore, the baseline data (samples collected immediately before the intrauterine infusion) of peripheral PMN (activity and expression of adhesion molecules), hemogram, and concentrations of haptoglobin, cortisol, and P4 were analyzed by ANOVA using the GLM procedure. The models included the effect of treatment. The MIXED procedure was used to analyze continuous data with repeated measurements (peripheral PMN activity, PMN adhesion molecule expression, hemogram, and concentrations of haptoglobin, cortisol, and P4). The repeated statement was used and the model included treatment, time, the interaction between treatment and time, and the baseline value as fixed effects. To control for the effect of uterine biopsy on outcomes, time of uterine biopsy collection was included as a fixed effect $(0=$ no biopsy; $6=$ biopsy $6 \mathrm{~h}$ after intrauterine infusion; $24=$ biopsy $24 \mathrm{~h}$ after intrauterine infusion). Cow was included in the model as the random effect and cows were nested within treatment. The structure of covariance (autoregressive, unstructured, or compound symmetry) was chosen according to the Bayesian information criteria.

Proportions of cows with a viable CL on $\mathrm{d} 0$ and proportion of cows that had luteolysis on $\mathrm{d} 1,2$, and 7 after intrauterine infusion were analyzed by Fisher's exact test using FREQ procedure.

Statistical significance was defined as $P \leq 0.05$ and statistical tendencies as $0.05<P \leq 0.10$.

\section{RESULTS}

\section{Uterine Biopsies}

Uterine expressions of mRNA for adhesion molecules [endothelial leukocyte adhesion molecule (E-selectin), intracellular adhesion molecule-1 (ICAM-1), and vascular cell adhesion molecule-1 (VCAM-1) ; $P \geq 0.28$, cytokines [tumor necrosis factor- $\alpha$ (TNF- $\alpha$ ), IL-1 $\beta$, IL-6, IL-8, and IL-10; $P \geq 0.33]$, and TLR-4 $(P=0.25)$ $6 \mathrm{~h}$ after intrauterine infusion were not different among treatments (Figure 1A). Similarly, $24 \mathrm{~h}$ after intrauterine infusion (Figure 1B), no differences were observed in the expression of mRNA for adhesion molecules (Eselectin, ICAM-1, and VCAM-1; $P \geq 0.60$ ), cytokines (TNF- $\alpha$, IL-1 $\beta$, IL-6, IL-8 and IL-10; $P \geq 0.37$ ), and TLR-4 $(P=0.40)$.

\section{Peripheral Blood PMN Activity}

At baseline, there were no differences among treatments regarding percentage of peripheral PMN expressing L-selectin $(P=0.99)$ and MAC-1 $(P=0.32)$, intensity of expression of L-selectin $(P=0.98)$ and MAC-1
$(P=0.38)$ by peripheral PMN, percentage of peripheral PMN positive for phagocytosis and oxidative burst $(P$ $=0.27)$, and intensity of phagocytosis $(P=0.65)$ and oxidative burst $(P=0.49)$ by peripheral PMN positive for phagocytosis and oxidative burst.

Percentage of peripheral PMN positive for expression of L-selectin $(P=0.74)$ and intensity of expression of L-selectin $(P=0.80)$ were not affected by treatment (Table 2). Although the percentage of peripheral PMN positive for expression of MAC-1 was not $(P=0.76)$ affected by treatment, treatment affected $(P=0.03)$ the intensity of expression of MAC-1 (Table 2). Peripheral PMN from LPS150 cows had $(P<0.01)$ and tended $(P=0.07)$ to have greater intensity of expression of MAC-1 than peripheral PMN from PBS and LPS300 cows, respectively (Table 2). Intensity of expression of MAC-1 by peripheral PMN of PBS and LPS300 cows was not $(P=0.39)$ different (Table 2$)$. The interaction
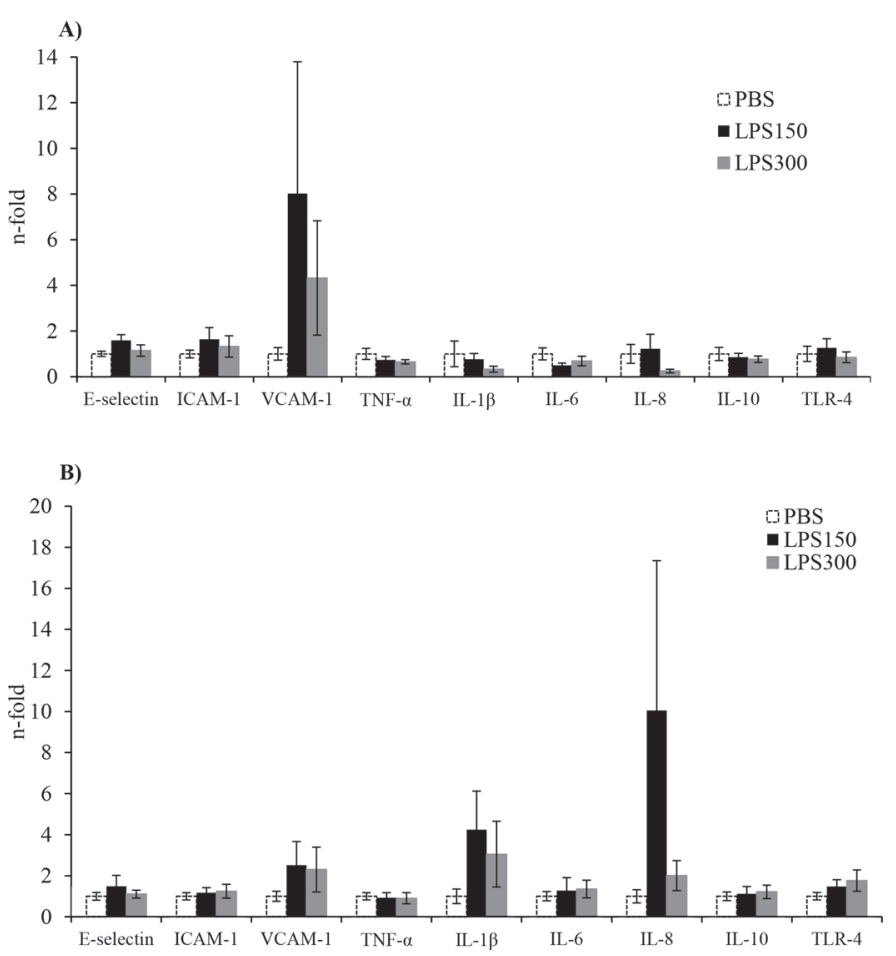

Figure 1. Effect of intrauterine infusion of Escherichia coli LPS on uterine mRNA expression of adhesion molecules (E-selectin, ICAM-1, VCAM-1), cytokines [tumor necrosis factor- $\alpha$ (TNF- $\alpha$ ), IL-1 $\beta$, IL-6, IL-8, IL-10], and toll-like receptor 4 (TLR-4) in uterine biopsies collected at $6 \mathrm{~h}(\mathrm{~A})$ and $24 \mathrm{~h}(\mathrm{~B})$ after infusion in cows diagnosed with purulent vaginal discharge (PVD). Treatments: PBS (6 h, $\mathrm{n}=16 ; 24$ $\mathrm{h}, \mathrm{n}=18)=$ cows with PVD treated with $20 \mathrm{~mL}$ of PBS; LPS150 (6 h, $\mathrm{n}=17 ; 24 \mathrm{~h}, \mathrm{n}=17)=$ cows with PVD treated with $150 \mu \mathrm{g}$ of $E$. coli LPS in $20 \mathrm{~mL}$ of PBS; and LPS300 $(6 \mathrm{~h}, \mathrm{n}=17 ; 24 \mathrm{~h}, \mathrm{n}=16)=$ cows with PVD treated with $300 \mu \mathrm{g}$ of E. coli LPS in $20 \mathrm{~mL}$ of PBS. The effects of treatment on uterine mRNA abundance were not significant $(P>0.25)$ for any of the genes examined at both 6 and $24 \mathrm{~h}$. Error bars represent the SEM. 


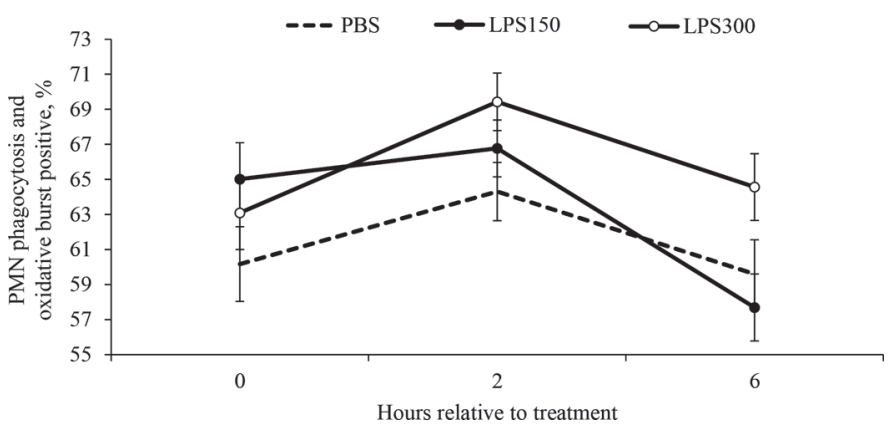

Figure 2. Effect of intrauterine infusion of Escherichia coli LPS on percentage of peripheral blood PMN positive for phagocytosis and oxidative burst in cows diagnosed with purulent vaginal discharge (PVD). Treatments: PBS $(\mathrm{n}=25)=$ cows with PVD treated with $20 \mathrm{~mL}$ of PBS; LPS150 $(\mathrm{n}=25)=$ cows with PVD treated with $150 \mu \mathrm{g}$ of $E$. coli LPS in $20 \mathrm{~mL}$ of PBS; and LPS300 $(\mathrm{n}=25)=$ cows with PVD treated with $300 \mu \mathrm{g}$ of $E$. coli LPS in $20 \mathrm{~mL}$ of PBS. At baseline, treatment was not $(P=0.27)$ associated with percentage of peripheral PMN positive for phagocytosis and oxidative burst. Effects of treatment, $P=0.03$; sample, $P<0.01$; and treatment by sample, $P=0.23$. Percentage of PMN positive for phagocytosis and oxidative burst was greater for LPS300 cows compared with PBS $(P=0.02)$ and LPS150 $(P=0.02)$ cows, but no $(P=0.90)$ differences in percentage of peripheral PMN positive for phagocytosis and oxidative burst between PBS and LPS150 cows were observed. Error bars represent the SEM.

between treatment and sample did not $(P=0.35)$ affect the intensity of expression of MAC-1 (Table 2).

Treatment affected $(P=0.03)$ the percentage of peripheral PMN positive for phagocytosis and oxidative burst (Figure 2). Greater percentage of peripheral PMN from LPS300 cows were positive for phagocytosis and oxidative burst compared with peripheral PMN from PBS $(P=0.02)$ and LPS150 $(P=0.02)$ cows (Table 2$)$. The interaction between treatment and sample did not $(P=0.23)$ affect the percentage of PMN positive for phagocytosis and oxidative burst (Figure 2). The intensity of phagocytosis $(P=0.35)$ and oxidative burst $(P$ $=0.63$ ) by peripheral PMN positive for phagocytosis and oxidative burst were not affected by treatment (Table 2).

\section{Hemogram}

No differences were observed among treatments, at baseline, regarding concentrations of leukocytes $(P=$ $0.36)$, granulocytes $(P=0.32)$, lymphocytes $(P=0.38)$, and monocytes $(P=0.97)$, and granulocyte:lymphocyte ratio $(P=0.70)$.

Intrauterine infusion of cows with PVD with LPS did not affect counts of leukocytes $(P=0.63)$, granulocytes $(P=0.56)$, lymphocytes $(P=0.21)$ and monocytes $(P$ $=0.35)$. Furthermore, treatment $\operatorname{did} \operatorname{not}(P=0.25)$ affect the granulocyte to lymphocyte ratio. The interaction between treatment and sample did not $(P \geq 0.58)$ affect hemogram parameters (Table 3 ). 


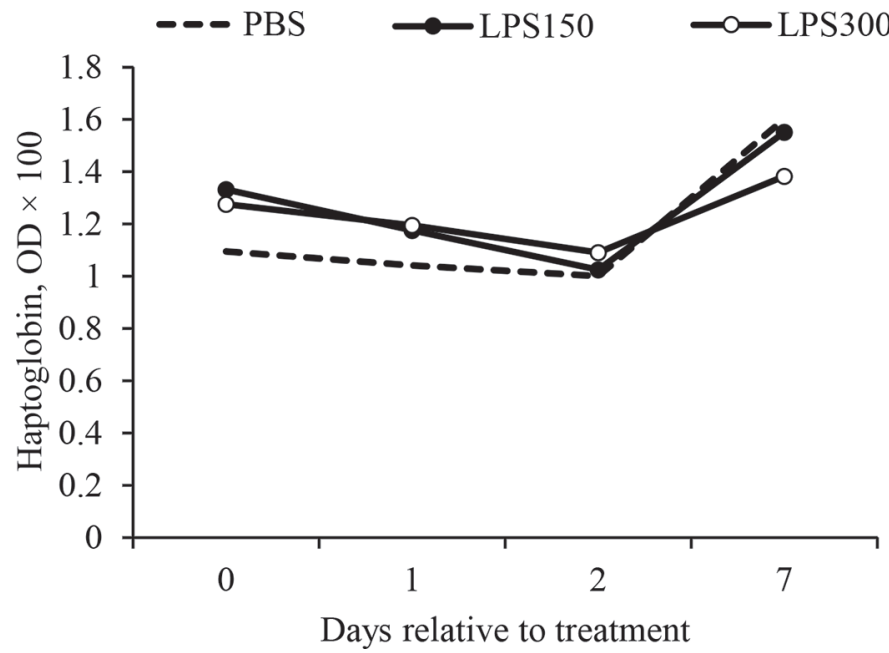

Figure 3. Effect of intrauterine infusion of Escherichia coli LPS on circulating haptoglobin concentration in cows diagnosed with purulent vaginal discharge (PVD). Haptoglobin concentrations are expressed in back-transformed values from logarithm to the base 10 of original results. Treatments: PBS $(\mathrm{n}=87)=$ cows with PVD treated with 20 $\mathrm{mL}$ of PBS; LPS150 $(\mathrm{n}=91)=$ cows with PVD treated with $150 \mu \mathrm{g}$ of $E$. coli LPS in $20 \mathrm{~mL}$ of PBS; and LPS300 $(\mathrm{n}=89)=$ cows with PVD treated with $300 \mu \mathrm{g}$ of $E$. coli LPS in $20 \mathrm{~mL}$ of PBS. At baseline, treatment was not $(P=0.12)$ associated with plasma haptoglobin concentration. Effect of treatment, $P=0.89$; sample, $P<0.01$; and interaction of treatment by sample, $P=0.26$. Back-transformed $95 \%$ confidence intervals were PBS: $\mathrm{d} 0=0.95,1.26 ; \mathrm{d} 1=0.89,1.22 ; \mathrm{d} 2=$ $0.85,1.17$; $7=1.36,1.88 ;$ LPS150: d $0=1.16,1.53$; d $1=1.00,1.38$; $\mathrm{d} 2=0.88,1.20 ; \mathrm{d} 7=1.32,1.82 ;$ and LPS300: $\mathrm{d} 0=1.11,1.46 ; \mathrm{d} 1$ $=1.02,1.40 ; \mathrm{d} 2=0.93,1.28 ; \mathrm{d} 7=1.18,1.62$. OD $=$ optical density.

\section{Cortisol, Haptoglobin, and Progesterone Assays}

At baseline, no $(P=0.12)$ association was present between treatment and plasma concentration of haptoglobin. Plasma haptoglobin concentration was not affected by treatment $(P=0.89)$ and by the interaction between treatment and sample $(P=0.26$; Figure 3$)$. Treatment was not $(P=0.52)$ associated with serum cortisol concentration at baseline and did not $(P=$ 0.96) affect serum cortisol concentration (Figure 4).

Proportion of cows with $\mathrm{P} 4 \geq 1.0 \mathrm{ng} / \mathrm{mL}$ before intrauterine infusion was not $(P=0.55)$ different

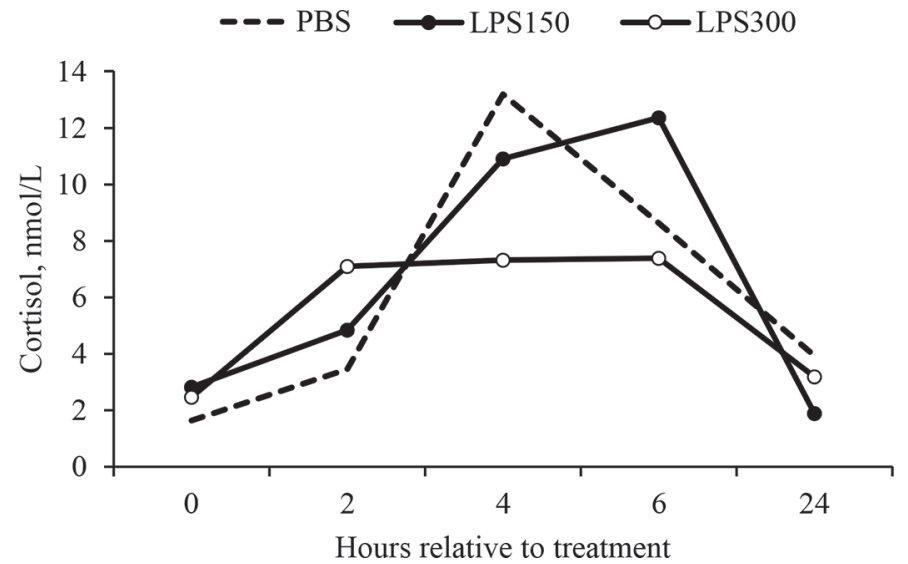

Figure 4. Effect of intrauterine infusion of Escherichia coli LPS on circulating cortisol concentration in cows diagnosed with purulent vaginal discharge (PVD). Cortisol concentrations are expressed in backtransformed values from logarithm to the base 10 of original results. Treatments: PBS $(\mathrm{n}=43)=$ cows with PVD treated with $20 \mathrm{~mL}$ of PBS; LPS150 $(\mathrm{n}=45)=$ cows with PVD treated with $150 \mu \mathrm{g}$ of $E$. coli LPS in $20 \mathrm{~mL}$ of PBS; and LPS300 $(\mathrm{n}=42)=$ cows with PVD treated with $300 \mu \mathrm{g}$ of $E$. coli LPS in $20 \mathrm{~mL}$ of PBS. At baseline, treatment was not $(P=0.51)$ associated with serum cortisol concentration. Effect of treatment, $P=0.96$; sample, $P<0.01$; and the interaction between treatment and sample, $P=0.12$. Back-transformed $95 \%$ confidence intervals were PBS: $0 \mathrm{~h}=0.83,3.25 ; 2 \mathrm{~h}=1.79,6.65 ; 4 \mathrm{~h}=$ 7.47, 23.30; $6 \mathrm{~h}=5.11,14.58 ; 24 \mathrm{~h}=1.93,8.02$; LPS150: $0 \mathrm{~h}=1.43$, $5.55 ; 2 \mathrm{~h}=2.53,9.25 ; 4 \mathrm{~h}=6.21,19.16 ; 6 \mathrm{~h}=7.35,20.79 ; 24 \mathrm{~h}=$ $0.93,3.83$; and LPS300: $0 \mathrm{~h}=1.23,4.93 ; 2 \mathrm{~h}=3.66,13.76 ; 4 \mathrm{~h}=4.12$, 13.00; $6 \mathrm{~h}=4.35,12.54 ; 24 \mathrm{~h}=1.55,6.55$.

among treatments $[\mathrm{PBS}=51.72 \%(45 / 87) ; \mathrm{LPS} 150=$ $43.96 \%$ (40/91); LPS300 $=44.94 \%$ (40/89)]. Similarly, treatment did not affect the proportions of cows with luteolysis by $1(P=0.42), 2(P=0.36)$, and 7 ( $P$ $=0.95) \mathrm{d}$ after intrauterine infusion (Figure $5 \mathrm{~A})$. No $(P=0.22)$ association was present between treatment and plasma concentration of $\mathrm{P} 4$ before the intrauterine infusion (Figure 5B). Among cows with a viable CL (P4 concentration $\geq 1 \mathrm{ng} / \mathrm{mL}$ ) before intrauterine infusion, treatment $(P=0.34)$ and the interaction between treatment and sample $(P=0.68)$ did not affect plasma $\mathrm{P} 4$ concentration (Figure 5B).

Table 3. Effect of intrauterine infusion of Escherichia coli LPS on hemogram parameters in cows diagnosed with purulent vaginal discharge (PVD)

\begin{tabular}{|c|c|c|c|c|c|c|}
\hline \multirow[b]{2}{*}{ Parameter ( \pm SEM) } & \multicolumn{3}{|c|}{ Treatment $(\mathrm{TRT})^{1}$} & \multicolumn{3}{|c|}{$P$-value } \\
\hline & PBS & LPS150 & LPS300 & TRT & Sample & TRT $\times$ sample \\
\hline White blood cells, $10^{9} / \mathrm{L}$ & $10.64 \pm 0.22$ & $10.93 \pm 0.21$ & $10.75 \pm 0.21$ & 0.63 & $<0.01$ & 0.77 \\
\hline Lymphocytes, $10^{9} / \mathrm{L}$ & $6.57 \pm 0.24$ & $6.77 \pm 0.23$ & $6.20 \pm 0.23$ & 0.21 & 0.04 & 0.59 \\
\hline Monocytes, $10^{9} / \mathrm{L}$ & $0.32 \pm 0.05$ & $0.22 \pm 0.05$ & $0.26 \pm 0.05$ & 0.35 & 0.72 & 0.72 \\
\hline Granulocyte:lymphocyte, \% & $75.27 \pm 4.77$ & $84.27 \pm 4.71$ & $85.48 \pm 4.59$ & 0.25 & 0.04 & 0.99 \\
\hline
\end{tabular}

${ }^{1}$ Treatments: PBS $(\mathrm{n}=38)=$ cows with PVD treated with $20 \mathrm{~mL}$ of PBS; LPS150 $(\mathrm{n}=40)=$ cows with PVD treated with $150 \mu \mathrm{g}$ of $E$. coli LPS in $20 \mathrm{~mL}$ of PBS; and LPS300 $(\mathrm{n}=41)=$ cows with PVD treated with $300 \mu \mathrm{g}$ of $E$. coli LPS in $20 \mathrm{~mL}$ of PBS. 


\section{DISCUSSION}

One of the hypotheses of the present study was that intrauterine infusion of cows positive for PVD with $E$. coli LPS would modulate uterine expression of genes involved in immune and inflammatory response. Lipopolysaccharide stimulates the production of TNF $\alpha$ and IL-1 (Wright, 1999), pro-inflammatory cytokines that mediate pyrexia, induction of acute-phase proteins, va-
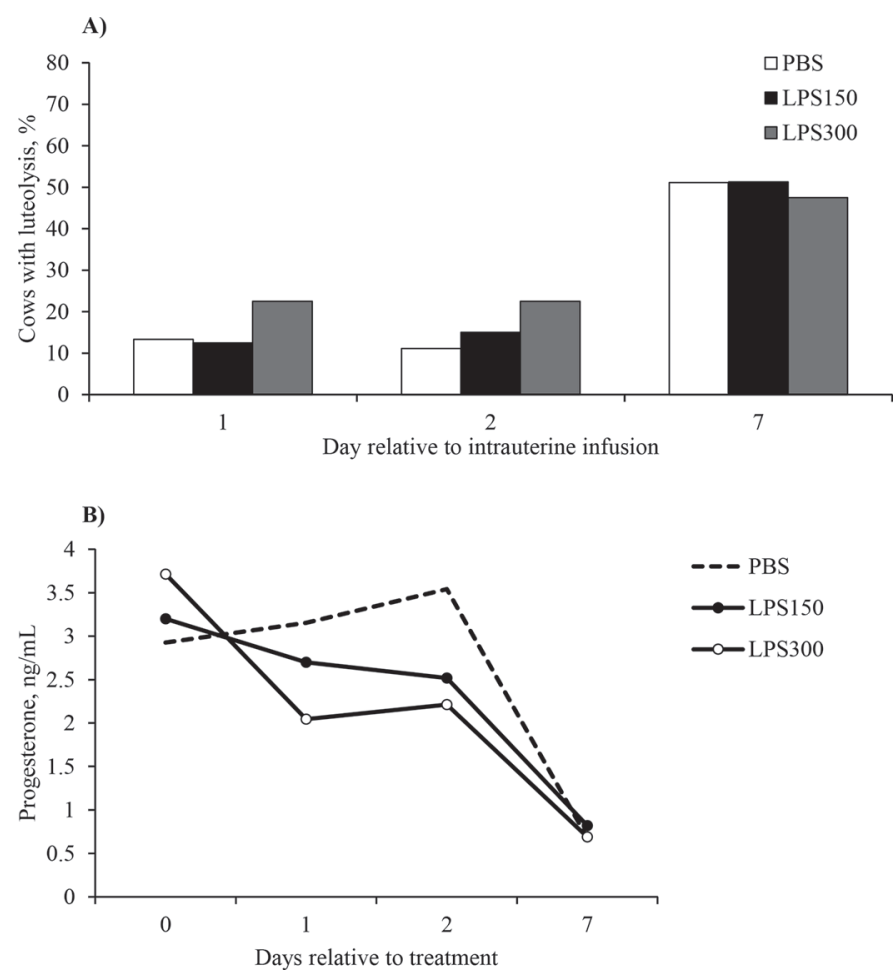

Figure 5. (A) Effect of intrauterine infusion of Escherichia coli LPS on the percentage of cows with luteolysis (progesterone $<1 \mathrm{ng}$ / $\mathrm{mL}) 1,2$, and $7 \mathrm{~d}$ after intrauterine infusion among cows that were positive for purulent vaginal discharge (PVD) and had a viable corpus luteum (progesterone $\geq 1 \mathrm{ng} / \mathrm{mL}$ ) before LPS treatment. Treatments: PBS $(\mathrm{n}=45)=$ cows with PVD treated with $20 \mathrm{~mL}$ of PBS; LPS150 $(\mathrm{n}=40)=$ cows with PVD treated with $150 \mu \mathrm{g}$ of E. coli LPS in 20 $\mathrm{mL}$ of PBS; and LPS300 $(\mathrm{n}=40)=$ cows with PVD treated with 300 $\mu \mathrm{g}$ of $E$. coli LPS in $20 \mathrm{~mL}$ of PBS. Treatment was not $(P=0.55)$ associated with percentage of cows with a viable corpus luteum immediately before intrauterine infusions. Effect of treatment on percentage of cows with luteolysis on d $1, P=0.42$; d $2, P=0.36$; and d $7, P=$ 0.95. (B) Effect of intrauterine infusion of $E$. coli LPS on circulating progesterone (P4) concentration in cows diagnosed with PVD. Only cows that had $\mathrm{P} 4 \geq 1 \mathrm{ng} / \mathrm{mL}$ in the sample collected immediately before intrauterine infusion were used. Progesterone concentrations are expressed in back-transformed values from logarithm to the base 10 of original results. Treatments: PBS $(\mathrm{n}=87)$; LPS150 $(\mathrm{n}=91)$; and LPS300 $(\mathrm{n}=89)$. At baseline, treatment was not $(P=0.22)$ associated with serum progesterone concentration. Effect of treatment, $P$ $=0.34$; sample, $P<0.01$; and the interaction between treatment and sample, $P=0.68$. Back-transformed $95 \%$ confidence intervals were PBS: d $0=2.43,3.52 ;$ d $1=2.04,4.88$; d $2=2.29,5.48$; d $7=0.44$, 1.05; LPS150: $\mathrm{d} 0=2.62,3.91 ; \mathrm{d} 1=1.68,4.34 ; \mathrm{d} 2=1.56,4.05 ; \mathrm{d} 7$ $=0.51,1.32$; LPS300: $\mathrm{d} 0=3.05,4.52 ; \mathrm{d} 1=1.29,3.25 ; \mathrm{d} 2=1.39$, $3.52 ; \mathrm{d} 7=0.43,1.10$. sodilatation, and stimulation of other cytokines (Marsh et al., 1994). Lipopolysaccharide induces IL-6 secretion, which upregulates expression of adhesion molecules on endothelial cells and leukocytes, favoring the process of leukocyte transmigration from blood circulation to inflamed tissues (Scheller et al., 2011). Lipopolysaccharide induced IL-8, a member of the chemokine family, attracts PMN to the site of inflammation, increases PMN ability to adhere to endothelial cells, increases PMN expression of integrin adhesion molecules LFA-1 (CD11aCD18) and MAC-1 (CD11bCD18), and induces PMN release of lysosomal enzymes (Harada et al., 1994). Transmigration of PMN from the blood vessels to the injured tissue occurs when PMN interacts with the endothelium, through cell adhesion molecules (CAM; Albelda et al., 1994; Kindt et al., 2006). The selectin family of CAM, including E-selectin that is expressed by endothelial cells (Binder and Ernst, 2011), is responsible for the initial stickiness of leukocytes to the endothelium, allowing leukocytes to roll along the vascular endothelium (Kindt et al., 2006). Cell surface glycoproteins [e.g., ICAM-1 (CD54) and VCAM (CD106)], part of the immunoglobulin superfamily, are expressed on vascular endothelial cells and bind to several members of the integrin family (Kindt et al., 2006). In the current experiment, however, uterine expression of mRNA for adhesion molecules (E-selectin, ICAM-1, and VCAM-1), cytokines (TNF- $\alpha$, IL-1 $\beta$, IL-6, IL-8, and IL-10), and toll-like receptor-4 was not affected by intrauterine infusion with LPS compared with intrauterine infusion with PBS. Using an in vitro model, Swangchan-Uthai et al. (2012) demonstrated that expression of mRNA for IL-1 $\beta$, IL-8, TNF, and TLR by endometrial cells were upregulated following a $24-\mathrm{h}$ incubation period with LPS. Furthermore, maximum mRNA expression for TNF and IL-1 $\beta$ were observed within $1 \mathrm{~h}$ after onset of culture with LPS and by 12 $h$ after onset of culture the mRNA expression for TNF and IL-1 $\beta$ was significantly reduced (Swangchan-Uthai et al., 2012). Therefore, we speculate that our sampling strategy may not have been appropriate to identify LPS-induced changes in mRNA expression in the uterus. Schmitz et al. (2004) demonstrated that mRNA expression for TNF- $\alpha$ in mammary tissue from quarters infused with LPS peaked at $3 \mathrm{~h}$ after treatment, and by $12 \mathrm{~h}$ after treatment, TNF- $\alpha$ mRNA expression was near baseline values. It is important to note that, in the current experiment, only cows positive for PVD were used. Purulent vaginal discharge is commonly associated with colonization of the uterus by gram-negative and gram-positive aerobes and anaerobes (Azawi, 2008) and upregulation of mRNA for IL-1 $\beta$, IL- 6 , IL- 8 , C-XC Motif Chemokine Ligand 5 (CXCL5), and TNFo at 20 to 50 DIM (Fischer et al., 2010; Galvão et al., 2011). 
Considering that LPS is a pathogen-associated molecular pattern present in the cell wall of gram-negative bacteria, it is possible that the mRNA expression of the genes evaluated in the current experiment was altered by possible bacteria colonization associated with PVD, limiting the effects of intrauterine LPS infusion.

The endometrial samples used for RNA extraction were collected using a biopsy instrument and are most likely from the intercaruncular endometrium with the presence of glands, stroma, and luminal epithelium (Geary et al., 2016). Furthermore, because the cows of the present study had PVD and were also treated with LPS, a large number of neutrophils were expected to be present in the luminal epithelium when the biopsies were collected. Neutrophils have a critical role regulating the development of inflammatory and immune responses and are known to produce a large number of cytokines (Tecchio et al., 2014). Therefore, our results regarding the expression of cytokines and TLR4 are likely a combination of expression by the endometrium and by PMN. Lipopolysaccharide-stimulated cytokines and chemokines were expected to alter peripheral PMN structure (expression of adhesion molecules) and activity (phagocytosis and oxidative burst). No differences among treatments were observed regarding PMN expression of L-selectin, a CAM expressed by PMN that binds to CD34 and GlyCAM-1 expressed by inflamed endothelium (Kindt et al., 2006). Polymorphonuclear leukocytes from LPS150 cows, however, had greater intensity of MAC-1 expression 2 and $6 \mathrm{~h}$ after intrauterine LPS infusion than PBS cows. Furthermore, a greater percentage of PMN from LPS300 cows was positive for phagocytosis and oxidative burst compared with PMN from PBS cows. Phagocytic processes are driven by controlled rearrangement of the actin cytoskeleton (May and Machesky, 2001), which allows PMN to internalize both opsonized and nonopsonized particles. Opsonization enhances phagocytosis and the 2 principal opsonin receptors of PMN are Fc receptors and the $\beta 2$ integrin MAC-1 (Lee et al., 2003). DiezFraille et al. (2004) demonstrated that L-selectin and MAC-1 expressions increased during the first $6 \mathrm{~h}$ after intramammary infusion with $E$. coli, but whereas L-selectin expression started to decrease $12 \mathrm{~h}$ after infusion, MAC-1 expression continued to increase. Obviously, L-selectin and MAC-1 are not the only adhesion molecules associated with PMN trafficking and activity, but they are important.

Despite having a relatively large number of animals, the current experiment had a limited number of samples and limited LPS doses to carefully investigate the changes in expression of these molecules in PMN. In a companion manuscript (Moraes et al., 2017), we described that intrauterine infusion with LPS caused a greater and more sustained influx of PMN into the uterus as compared with PBS infusions. In addition, treatment of PVD cows with $150 \mu \mathrm{g}$ of LPS improved likelihood of pregnancy to the first postpartum AI. Thus, further experiments are encouraged to better explain the mechanisms through which LPS improves uterine health and reproductive performance.

One limitation of the present study is that the bacterial composition of the uterus before and after treatment was not investigated. Recent studies have used metagenomics to gather information of the bacterial composition of the bovine uterine microbiome of health, metritic (Santos et al., 2011; Peng et al., 2013) and endometritic dairy cows (Santos and Bicalho, 2012). For instance, Peng et al. (2013) reported that on d 10 postpartum Bacteroidetes, Firmicutes, and Fusobacteria were the dominant group of bacteria in both healthy and metritic cows. Results from quantitative PCR, however, revealed that metritic cows had higher bacterium loads of Bacteroidetes, Peptostreptococcus, and Fusobacterium compared with healthy cows on d 10. Therefore, it is possible that the intrauterine infusions of LPS affected the dynamics of bacterial growth in the uterus, resulting in proliferation of beneficial microorganisms, which lead to improvements in uterine recovery and better reproductive performance (Moraes et al., 2017).

In the current experiment, intrauterine infusion with LPS did not affect hemogram parameters of cows positive for PVD. Intramammary infusion with $1,000 \mu \mathrm{g}$ of LPS resulted in leukopenia 6 to $12 \mathrm{~h}$ after treatment (nadir $6 \mathrm{~h}$ after treatment) and a peak concentration of immature neutrophils in the circulation $6 \mathrm{~h}$ after LPS infusion (Mehrzad et al., 2001). Leukocytosis was observed, however, from 24 to $48 \mathrm{~h}$ after intramammary infusion with LPS (Mehrzad et al., 2001). Although intrauterine infusion with LPS resulted in numerically greater granulocyte to lymphocyte ratio from 6 to 48 $\mathrm{h}$ after infusion, it is possible that the smaller LPS doses used in the current experiment (150 and $300 \mu \mathrm{g}$ ) compared with the dose used by Mehrzad et al. (2001) prevented us from observing statistical differences.

Concentrations of haptoglobin were not different among treatments in the current experiment. Similarly, Williams et al. (2008) did not observe an increase in the concentration of the acute phase protein $\alpha-1$ acid glycoprotein among Holstein heifers treated with $3 \mu \mathrm{g} / \mathrm{kg}$ of LPS intra-uterus (Williams et al., 2008). In the current experiment, the LPS150 and the LPS300 cows received approximately 0.27 and $0.54 \mu \mathrm{g}$ of LPS per $\mathrm{kg}$ of live BW. Lactating dairy cows that received $100 \mu \mathrm{g}$ of LPS through intravenous administration, however, had a 
significant increase in circulating haptoglobin concentrations by $12 \mathrm{~h}$ after treatment (Hiss et al., 2004). We speculate that the lack of systemic inflammatory response to the intrauterine LPS infusion in the current experiment may have resulted from a minimal increase in LPS concentration in the circulation. Blood cortisol concentration was not affected by treatment in the current experiment. Lipopolysaccharide induced secretion of cytokines (e.g., TNFo, IL-1, and IL-6) stimulates the secretion of corticotropin-releasing hormone by the hypothalamus, resulting in secretion of adrenocorticotropic hormone by the pituitary and glucocorticoids by the adrenal cortex (Beishuizen and Thijs, 2003). The lack of differences among treatments regarding cortisol concentration may result from minimal increase in LPS concentration in the circulation or handling induced stress during sample collection, since all cows had a significant rise in cortisol concentration 4 to $6 \mathrm{~h}$ after intrauterine infusions in the current experiment.

The lack of differences in percentages of cows with $\mathrm{P} 4$ concentration $\geq 1 \mathrm{ng} / \mathrm{mL}$ at the moment of intrauterine infusion is important because $\mathrm{P} 4$ is an immunosuppressant (Siiteri et al., 1977; Hansen, 2013). Expression of mRNA for pro-inflammatory chemokines and cytokines (CXCL5, IL-1 $\beta$, and IL-8) are reduced during the diestrus compared with the proestrus (Fischer et al., 2010). Moreover, in vitro, $\mathrm{P} 4$ inhibits the production of $\mathrm{PGE}_{2}$ and $\mathrm{PGF}_{2 \alpha}$ by endometrial stromal and epithelial cells upon LPS challenge (Herath et al., 2006). Prostaglandins play a key role in the regulation of the inflammatory response (Ricciotti and FitzGerald, 2011). As part of the inflammatory response to the intrauterine infusion with LPS, we speculated that secretion of $\mathrm{PGE}_{2}$ and $\mathrm{PGF}_{2 \alpha}$ would increase, which could cause luteolysis. Among cows with a CL at the time of treatment with LPS, however, there was no effect of LPS intrauterine infusion on $\mathrm{P} 4$ concentration. PiotrowskaTomala et al. (2015) demonstrated that in vitro and in vivo challenges with LPS stimulated the secretion of $\mathrm{PGE}_{2}, \mathrm{PGF}_{2 \alpha}$, and 13,14-dihydro,15-keto- $\mathrm{PGF}_{2 \alpha}$ by the bovine mammary gland. Lima et al. (2015) demonstrated that $12 \mathrm{~h}$ after intrauterine treatment with TNF- $\alpha$ and Trueperella pyogenes there was an increase in the expression of mRNA for oxytocin receptor in the endometrium. Herath et al. (2006) demonstrated an increased in the ratio of PGE to PGF following challenge of endometrial epithelial and stromal cells with LPS. Because only small doses of LPS were used for intrauterine treatment in present experiment, along with the fact that treated cows had PVD and possibly gram-negative bacteria in the uterus, it is not surprising that luteal function was unaffected by intrauterine LPS infusion.

\section{CONCLUSIONS}

Intrauterine infusion of $E$. coli LPS in cows positive for PVD did not affect uterine mRNA expression of genes associated with inflammatory and immune responses. Despite the lack of effect of intrauterine LPS infusion on hemogram parameters, and circulating concentrations of cortisol, haptoglobin, or P4, intrauterine LPS infusion stimulated circulating PMN expression of MAC-1 molecules and increased the percentage of PMN positive for phagocytosis and oxidative burst. Thus, we speculate that sampling time was not appropriate to detect changes in uterine mRNA expression following intrauterine LPS infusion and that circulating LPS concentrations following intrauterine LPS infusion might have been minimum and only able to stimulate PMN activity. Additional experiments are necessary to determine the exact mechanism through which intrauterine infusion of PVD-positive cows with E. coli LPS may resolve uterine infections and improve uterine health.

\section{ACKNOWLEDGMENTS}

The authors thank the owner and staff of the dairy farm for the use of their cows and facilities and the Grant-in-Aid Program of the Office of the Vice President for Research of the University of Minnesota for funding this study.

\section{REFERENCES}

Albelda, S. M., C. W. Smith, and P. A. Ward. 1994. Adhesion molecules and inflammatory injury. FASEB J. 8:504-512.

Azawi, O. I. 2008. Postpartum uterine infection in cattle. Anim. Reprod. Sci. 105:187-208.

Beishuizen, A., and L. G. Thijs. 2003. Endotoxin and the hypothalamo-pituitary-adrenal (HPA) axis. J. Endotoxin Res. 9:3-24.

Binder, F. P., and B. Ernst. 2011. E- and P-selectin: Differences, similarities and implications for the design of P-selectin antagonists. Chimia (Aarau) 65:210-213.

Cerri, R. L., I. M. Thompson, I. H. Kim, A. D. Ealy, P. J. Hansen, C. R. Staples, J. L. Li, J. E. Santos, and W. W. Thatcher. 2012. Effects of lactation and pregnancy on gene expression of endometrium of Holstein cows at day 17 of the estrous cycle or pregnancy. J. Dairy Sci. 95:5657-5675.

Chapwanya, A., K. G. Meade, M. L. Doherty, J. J. Callanan, J. F. Mee, and C. O'Farrelly. 2009. Histopathological and molecular evaluation of Holstein-Friesian cows postpartum: Toward an improved understanding of uterine innate immunity. Theriogenology 71:1396-1407.

Diez-Fraille, A., J. Mehrzad, E. Meyer, L. Duchateau, and C. Burvenich. 2004. Comparison of L-selectin and Mac-1 expression on blood and milk neutrophils during experimental Escherichia coli-induced mastitis in cows. Am. J. Vet. Res. 65:1164-1171.

Dubuc, J., T. F. Duffield, K. E. Leslie, J. S. Walton, and S. J. LeBlanc. 2010. Definitions and diagnosis of postpartum endometritis in dairy cows. J. Dairy Sci. 93:5225-5233. 
Ferguson, J. D., D. T. Galligan, and N. Thomsen. 1994. Principal descriptors of body condition score in Holstein cows. J. Dairy Sci. 77:2695-2703.

Fischer, C., M. Drillich, S. Odau, W. Heuwieser, R. Einspanier, and C. Gabler. 2010. Selected pro-inflammatory factor transcripts in bovine endometrial epithelial cells are regulated during the oestrous cycle and elevated in case of subclinical or clinical endometritis. Reprod. Fertil. Dev. 22:818-829.

Galvão, K. 2012. Postpartum uterine diseases in dairy cows. Anim. Reprod. 9:290-296.

Galvão, K. N., N. R. Santos, J. S. Galvão, and R. O. Gilbert. 2011. Association between endometritis and endometrial cytokine expression in postpartum Holstein cows. Theriogenology 76:290-299.

Geary, T. W., G. W. Burns, J. G. N. Moraes, J. I. Moss, A. C. Denicol, K. B. Dobbs, M. S. Ortega, P. J. Hansen, M. E. Wehrman, H. Neibergs, and E. O'Neil. 2016. Identification of beef heifers with superior uterine capacity for pregnancy. Biol. Reprod. 95:47.

Gilbert, R. O.. S. T. Shin, C. L. Guard, H. N. Erb, and M. Frajblat. 2005. Prevalence of endometritis and its effects on reproductive performance of dairy cows. Theriogenology 64:1879-1888.

González, R. N., J. S. Cullor, D. E. Jasper, T. B. Farver, R. B. Bushnell, and M. N. Oliver. 1989. Prevention of clinical coliform mastitis in dairy cows by a mutant Escherichia coli vaccine. Can. J. Vet. Res. 53:301-305.

Hammon, D. S., I. M. Evjen, T. R. Dhiman, J. P. Goff, and J. L. Walters. 2006. Neutrophil function and energy status in Holstein cows with uterine health disorders. Vet. Immunol. Immunopathol. 113:21-29

Hansen, P. J. 2013. Maternal immunological adjustments to pregnancy and parturition in ruminants and possible implications for postpartum uterine health: Is there a prepartum-postpartum nexus? J. Anim. Sci. 91:1639-1649.

Harada, A., N. Sekido, T. Akahoshi, T. Wada, N. Mukaida, and K. Matsushima. 1994. Essential involvement of interleukin-8 (IL-8) in acute inflammation. J. Leukoc. Biol. 56:559-564.

Herath, S., D. P. Fischer, D. Werling, E. J. Williams, S. T. Lilly, H. Dobson, C. E. Bryant, and I. M. Sheldon. 2006. Expression and function of toll-like receptor 4 in the endometrial cells of the uterus. Endocrinology 147:562-570.

Hiss, S., M. Mielenz, R. M. Bruckmaier, and H. Sauerwein. 2004. Haptoglobin concentrations in blood and milk after endotoxin challenge and quantification of mammary $\mathrm{Hp}$ mRNA expression. J. Dairy Sci. 87:3778-3784.

Hulbert, L. E., J. A. Carroll, N. C. Burdick, R. D. Randel, M. S. Brown, and M. A. Ballou. 2011. Innate immune responses of temperamental and calm cattle after transportation. Vet. Immunol. Immunopathol. 143:66-74.

Kasimanickam, R., T. F. Duffield, R. A. Foster, C. J. Gartley, K. E. Leslie, J. S. Walton, and W. H. Johnson. 2005. The effect of a single administration of cephapirin or cloprostenol on the reproductive performance of dairy cows with subclinical endometritis. Theriogenology 63:818-830.

Kindt, T. J., R. A. Goldsby, B. A. Osborne, and J. Kuby. 2006. Kuby Immunology. WH Freeman \& Company, New York, NY.

LeBlanc, S. J. 2008. Postpartum uterine disease and dairy herd reproductive performance: A review. Vet. J. 176:102-114.

LeBlanc, S. J., T. F. Duffield, K. E. Leslie, K. G. Bateman, G. P. Keefe, J. S. Walton, and W. H. Johnson. 2002. The effect of treatment of clinical endometritis on reproductive performance in dairy cows. J. Dairy Sci. 85:2237-2249.

Lee, W. L., R. E. Harrison, and S. Grinstein. 2003. Phagocytosis by neutrophils. Microbes Infect. 5:1299-1306.

Li, Q., and I. M. Verma. 2002. NF-kappaB regulation in the immune system. Nat. Rev. Immunol. 2:725-734

Lima, F. S., L. F. Greco, R. S. Bisinotto, E. S. Ribeiro, N. M. Martinez, W. W. Thatcher, J. E. P. Santos, M. K. Reinhard, and K. N. Galvão. 2015. Effects of intrauterine infusion of Trueperella pyogenes on endometrial mRNA expression of proinflammatory cytokines and luteolytic cascade genes and their association with luteal life span in dairy cows. Theriogenology 84:1263-1272.
Lu, Y. C., W. C. Yeh, and P. S. Ohashi. 2008. LPS/TLR4 signal transduction pathway. Cytokine 42:145-151.

MacKenzie, K. F., M. W. Van Den Bosch, S. Naqvi, S. E. Elcombe, V. A. McGuire, A. D. Reith, P. J. Blackshear, J. L. Dean, and J. S. Arthur. 2013. MSK1 and MSK2 inhibit lipopolysaccharideinduced prostaglandin production via an interleukin-10 feedback loop. Mol. Cell. Biol. 33:1456-1467.

Marsh, C. B., S. A. Moore, H. A. Pope, and M. D. Wewers. 1994. IL1ra suppresses endotoxin-induced IL-1 beta and TNF-alpha release from mononuclear phagocytes. Am. J. Physiol. 267:L39-L45.

Masera, J., B. K. Gustafsson, M. M. Afiefy, C. M. Stowe, and G. P. Bergt. 1980. Disposition of oxytetracycline in the bovine genital tract: Systemic vs intra-uterine administration. J. Am. Vet. Med. Assoc. 176:1099-1102

Mateus, L., L. Lopes da Costa, H. Carvalho, P. Serra, and J. Robalo Silva. 2002. Blood and intra-uterine leukocyte profile and function in dairy cows that spontaneously recovered from postpartum endometritis. Reprod. Domest. Anim. 37:176-180.

May, R. C., and L. M. Machesky. 2001. Phagocytosis and the actin cytoskeleton. J. Cell Sci. 114:1061-1077.

McDougall, S., R. Macaulay, and C. Compton. 2007. Association between endometritis diagnosis using a novel intravaginal device and reproductive performance in dairy cattle. Anim. Reprod. Sci. 99:9-23.

Mehrzad, J., H. Dosogne, E. Meyer, and C. Burvenich. 2001. Local and systemic effects of endotoxin mastitis on the chemiluminescence of milk and blood neutrophils in dairy cows. Vet. Res. 32:131-144.

Mogensen, T. H. 2009. Pathogen recognition and inflammatory signaling in innate immune defenses. Clin. Microbiol. Rev. 22:240-273.

Moraes, J. G. N., P. R. B. Silva, L. G. D. Mendonça, A. A. Scanavez, J. C. C. Silva, and R. C. Chebel. 2017. Effects of intra-uterine infusion of Escherichia coli lipopolysaccharide on uterine health, resolution of purulent vaginal discharge and reproductive performance of lactating dairy cows. J. Dairy Sci. 100:4772-4783. https://doi. org/10.3168/jds.2016-11630.

NAHMS (National Animal Health Monitoring System). 2007. Dairy 2007. Part I: Reference of dairy cattle health and management practices in the United States. Centers for Epidemiology and Animal Health/USDA/APHIS/VS, Fort Collins, CO.

O'Neill, L. A., and A. G. Bowie. 2007. The family of five: TIR-domaincontaining adaptors in toll-like receptor signalling. Nat. Rev. Immunol. 7:353-364.

Oxender, W. D., and B. E. Seguin. 1976. Bovine intra-uterine therapy. J. Am. Vet. Med. Assoc. 168:217-219.

Ozawa, M. Q. E. Yang, and A. D. Ealy. 2013. The expression of fibroblast growth factor receptors during early bovine conceptus development and pharmacological analysis of their actions on trophoblast growth in vitro. Reproduction 145:191-201.

Park, B. S., D. H. Song, H. M. Kim, B. S. Choi, H. Lee, and J. O. Lee. 2009. The structural basis of lipopolysaccharide recognition by the TLR4-MD-2 complex. Nature 458:1191-1195

Peng, Y., Y. Wang, S. Hang, and W. Zhu. 2013. Microbial diversity in uterus of healthy and metritic postpartum Holstein dairy cows. Folia Microbiol. (Praha) 58:593-600

Piotrowska-Tomala, K. K., M. M. Bah, K. Jankowska, K. Lukasik, P. Warmowski, A. M. Galvão, and D. J. Skarzynski. 2015. Lipopolysaccharides, cytokines, and nitric oxide affect secretion of prostaglandins and leukotrienes by bovine mammary gland during experimentally induced mastitis in vivo and in vitro. Domest. Anim. Endocrinol. 52:90-99.

Ricciotti, E., and G. A. FitzGerald. 2011. Prostaglandins and inflammation. Arterioscler. Thromb. Vasc. Biol. 31:986-1000.

Santos, T. M., and R. C. Bicalho. 2012. Diversity and succession of bacterial communities in the uterine fluid of postpartum metritic, endometritic and healthy dairy cows. PLoS One 7:e53048.

Santos, T. M. A., R. O. Gilbert, and R. C. Bicalho. 2011. Metagenomic analysis of the uterine bacterial microbiota in healthy and metritic postpartum dairy cows. J. Dairy Sci. 94:291-302.

Scheller, J., A. Chalaris, D. Schmidt-Arras, and S. Rose-John. 2011. The pro- and anti-inflammatory properties of the cytokine interleukin-6. Biochim. Biophys. Acta 1813:878-888. 
Schmitz, S., M. W. Pfaffl, H. H. Meyer, and R. M. Bruckmaier. 2004 Short-term changes of mRNA expression of various inflammatory factors and milk proteins in mammary tissue during LPS-induced mastitis. Domest. Anim. Endocrinol. 26:111-126.

Schroder, K., P. J. Hertzog, T. Ravasi, and D. A. Hume. 2004. Interferon-gamma: An overview of signals, mechanisms and functions. J. Leukoc. Biol. 75:163-189.

Sheldon, I. M., J. Cronin, L. Goetze, G. Donofrio, and H. J. Schuberth 2009. Defining postpartum uterine disease and the mechanisms of infection and immunity in the female reproductive tract in cattle. Biol. Reprod. 81:1025-1032.

Sheldon, I. M., G. S. Lewis, S. LeBlanc, and R. O. Gilbert. 2006. Defining postpartum uterine disease in cattle. Theriogenology 65:1516-1530

Siiteri, P. K., F. Febres, L. E. Clemens, R. J. Chang, B. Gondos, and D. Stites. 1977. Progesterone and maintenance of pregnancy: Is progesterone nature's immunosuppressant? Ann. N. Y. Acad. Sci 286:384-397.

Singh, J., S. S. Sidhu, G. S. Dhaliwal, G. R. Pangaonkar, A. S. Nanda, and A. S. Grewal. 2000. Effectiveness of lipopolysaccharide as an intra-uterine immunomodulator in curing bacterial endometritis in repeat breeding cross-bred cows. Anim. Reprod. Sci. 59:159-166.

Swangchan-Uthai, T., C. R. M. Lavender, Z. Cheng, A. A. FouladiNashta, and D. C. Wathes. 2012. Time course of defense mechanisms in bovine endometrium in response to lipopolysaccharide. Biol. Reprod. 87:135.

Tecchio, C., A. Micheletti, and M. A. Cassatella. 2014. Neutrophil-derived cytokines: Facts beyond expression. Front. Immunol. 5:508. https://doi.org/10.3389/fimmu.2014.00508.

Williams, E. J., D. P. Fischer, D. U. Pfeiffer, G. C. England, D. E. Noakes, H. Dobson, and I. M. Sheldon. 2005. Clinical evaluation of postpartum vaginal mucus reflects uterine bacterial infection and the immune response in cattle. Theriogenology 63:102-117.

Williams, E. J., K. Sibley, A. N. Miller, E. A. Lane, J. Fishwick, D. M. Nash, S. Herath, G. C. England, H. Dobson, and I. M. Sheldon. 2008. The effect of Escherichia coli lipopolysaccharide and tumour necrosis factor alpha on ovarian function. Am. J. Reprod. Immunol. 60:462-473

Wright, S. D. 1999. Toll, a new piece in the puzzle of innate immunity. J. Exp. Med. 189:605-609. 